\title{
Rare but large bivalves alter benthic respiration and nutrient recycling in riverine sediments
}

\author{
Sara Benelli 1 - Marco Bartoli • Erica Racchetti · \\ Paula Carpintero Moraes • Mindaugas Zilius • \\ Irma Lubiene • Elisa Anna Fano
}

Received: 24 February 2016/Accepted: 11 July 2016/Published online: 20 July 2016

(C) Springer Science+Business Media Dordrecht 2016

\begin{abstract}
Bioturbation studies have generally analyzed small and abundant organisms while the contribution to the benthic metabolism by rare, large macrofauna has received little attention. We hypothesize that large, sporadic bivalves may represent a hot spot for benthic processes due to a combination of direct and indirect effects as their metabolic and bioturbation activities. Intact riverine sediments with and without individuals of the bivalve Sinanodonta woodiana were collected in a reach with transparent water, where the occurrence of the mollusk was clearly visible. The bivalve metabolism and its effects on sedimentary fluxes of dissolved gas and nutrients were measured via laboratory incubations of intact cores under controlled conditions. S. woodiana contributed significantly to $\mathrm{O}_{2}$ and $\mathrm{TCO}_{2}$ benthic fluxes through its respiration and to $\mathrm{NH}_{4}^{+}, \mathrm{SRP}$ and $\mathrm{SiO}_{2}$
\end{abstract}

Handling Editor: Piet Spaak.

S. Benelli $(\bowtie) \cdot$ E. A. Fano

Department of Life Sciences and Biotechnologies,

University of Ferrara, Via Luigi Borsari 46,

44121 Ferrara, Italy

e-mail: sara.benelli@unife.it

M. Bartoli · E. Racchetti - P. C. Moraes

Department of Life Sciences, University of Parma,

Viale Usberti 33/A, 43124 Parma, Italy

M. Bartoli · M. Zilius · I. Lubiene

Marine Science and Technology Center, University of

Klaipeda, H. Manto 84 st., 92294 Klaipeda, Lithuania regeneration via its excretion. The bivalve significantly stimulated also microbial denitrification and determined a large efflux of $\mathrm{CH}_{4}$, likely due a combination of bioturbation and biodeposition activities or to anaerobic metabolism within the mollusk gut. This study demonstrates that a few, large individuals of this bivalve produce significant effects on aerobic and anaerobic benthic metabolism and nutrient mobilization. Random sediment sampling in turbid waters seldom catches these important effects due to low densities of large fauna.

Keywords Sediment - Sinanodonta woodiana . Metabolism $\cdot$ Excretion $\cdot$ Fluxes

\section{Introduction}

In soft sediments, bioturbation has profound effects on the physical, geochemical and biological properties of the substratum, as well as on benthic-pelagic coupling (Aller 1982; Palmer et al. 1997). Such effects depend upon feeding, defecation, irrigation, excretion and reworking activities (Kristensen et al. 2012). If and how macrofauna affect sedimentary processes was investigated under different perspectives and with a wide range of experimental approaches (Pelegrí and Blackburn 1995; Hansen et al. 1996; Prins et al. 1998; Vaughn and Hakenkamp 2001; Stief 2013). Earlier studies have focused on small, active and abundant 
organisms, with densities sometimes over 10,000 ind $\mathrm{m}^{-2}$, and generally burrowing in the sediment (Gallepp 1979; Pelegrí et al. 1994; Svensson 1997). To this purpose, incubations of sieved sediments added with increasing numbers of small organisms were performed, to test for process rates versus macrofauna density (Pelegrí and Blackburn 1995; Svensson 1997; Nizzoli et al. 2007). Burrowing macrofauna was demonstrated to stimulate the activity of bacteria and to alter the ratio between advective and diffusive processes and the volume of oxic and anoxic sediments ( $\mathrm{Na}$ et al. 2008; Bartoli et al. 2009). Burrowers may simultaneously increase nitrogen $(\mathrm{N})$ loss and enhance its recycling from pore waters, particularly during early colonization phases (Bartoli et al. 2000; Nizzoli et al. 2007). Stief (2013) analyzed the net effects of macrofauna on $\mathrm{N}$, a deeply studied bioturbated nutrient, and concluded that in most studies macrofauna stimulated $\mathrm{NH}_{4}^{+}$recycling to a much larger extent than $\mathrm{N}$ loss via denitrification. Burrowers may also enhance the retention capacity of sediments toward phosphorous (P), increasing the pool of reactive iron (Norkko et al. 2012).

More recently, farmed or invasive filter feeding bivalves as Tapes philippinarum or Dreissena polymorpha received large attention due to their ability to control or stimulate phytoplankton, oxygen $\left(\mathrm{O}_{2}\right)$ and nutrient dynamics, sometimes at the whole ecosystem level (Caraco et al. 2000; Bartoli et al. 2001; Higgins and Zanden 2010; Stadmark and Conley 2011; Ruginis et al. 2014). Due to their high densities, filter feeding bivalves may remove large amounts of particulate matter from the water column and produce high amounts of biodeposits as feces and pseudofeces, which enhance microbial activity and alter sediment properties (Nizzoli et al. 2014; Ruginis et al. 2014). They also excrete large amounts of nutrients, promoting the so-called benthic-pelagic coupling, potentially favoring pelagic or benthic primary producers other than phytoplankton (Bartoli et al. 2001, 2003; Murphy et al. 2015).

The effect of large bivalves, averaging few individuals per square meter, has been less studied (Nalepa et al. 1991; Strayer et al. 1994; Vaughn et al. 2004; Strayer 2014). This is likely due to their metabolism, which is supposed to be slow, their low density and their limited movements within sediments. These three combined factors are considered to produce little effects on the benthic system. Moreover, large, occasional bivalves are difficult to include in random sediment sampling, unless many replicate cores with large diameters are collected (Glud and Blackburn 2002). As they are generally not included in benthic flux measurements, their contribution to the metabolism of sediment is underestimated or simply not considered.

In this work, we analyzed the effects of a large mollusk (Sinanodonta woodiana, Lea 1834) on benthic respiration and nutrient regeneration, using intact sediment cores collected in a canal with transparent water and soft sediments. The mollusk under investigation can reach several hundreds of grams as wet weight and moves producing clearly visible paths on the sediment surface, probably due to feeding, reproductive needs or water level variations (Balfour and Smock 1995; Schwalb and Pusch 2007). Burrowing and lateral movements of $S$. woodiana, due to the dimension of the mollusk, may produce a large sediment reworking. S. woodiana may eat sediments around siphons (i.e., benthic microalgae), resuspend and filter recently deposited matter or may feed pedally, as suggested by different works on freshwater mollusks (Hakenkamp and Palmer 1999; Raikow and Hamilton 2001; Nichols et al. 2005). These possibilities provide a competitive advantage in clear water areas with limited phytoplankton availability. Vertical and lateral movements by large unionids or incomplete closing of the valves may introduce $\mathrm{O}_{2}$ - and nitrate $\left(\mathrm{NO}_{3}^{-}\right)$-rich water within sediments, with a net reoxidation of chemically reduced compounds (i.e., iron and manganese pools) and stimulation of $\mathrm{O}_{2}$ and $\mathrm{NO}_{3}^{-}$respiration. Simultaneously, sediment reworking by this large organism may introduce in subsurface sediments labile organic matter as benthic algae, feces and pseudofeces that may stimulate anaerobic processes as metal reduction or methanogenesis. Different studies analyzed the effect of bivalves on benthic biogeochemistry in phytoplankton-rich ecosystems and quantified the balance between suspended matter removal via filtration and benthic regeneration (Nizzoli et al. 2006; Murphy et al. 2015). Comparatively, the effect of large mollusks on benthic-pelagic coupling and microbial respiration in oligotrophic sites, where sediments may be an important food source, was less studied (Strayer 2014). We hypothesized that these organisms may represent 
biogeochemical hot spots exerting both direct (i.e., due to their metabolism) and indirect (due to their feeding strategy and sediment reworking) effects, relevant at the whole benthic system scale.

\section{Materials and methods}

\section{Sampling procedure}

Water, sediments and bivalves were collected in November 2015 from a canal tributary of the Mincio River (Northern Italy). The sampling site is characterized by shallow $(z=30 \mathrm{~cm})$, transparent (planktonic Chl $\left.a<1 \mu \mathrm{g} \mathrm{L}^{-1}\right), \mathrm{NO}_{3}^{-}$-rich $\left(30<\mathrm{NO}_{3}^{-}<50 \mu \mathrm{M}\right)$ and slow flowing $\left(<10 \mathrm{~cm} \mathrm{~s}^{-1}\right)$ water originating from a nearby spring and overlying a thick layer $(\sim 40 \mathrm{~cm})$ of fine organic sediments. In the whole area, the siphons of $S$. woodiana were clearly visible, identifying the position of single or small groups (2-4) of organisms (Fig. 1). In Italy, S. woodiana is a non- native and invasive species, documented since 1996 (Manganelli et al. 1998). The density of the bivalve was estimated by random positioning of $1 \mathrm{~m}^{2}$ quadrats on the sediment surface $(n=10)$ and by counting the individuals.

Intact sediment cores with $(n=13)$ and without ( $n=11)$ mollusks were collected by means of Plexiglass liners (i.d. $20 \mathrm{~cm}$, height $40 \mathrm{~cm}$ ) in order to measure benthic respiration and nutrient fluxes. Liners were pushed by hand in the fluffy sediment; nearly $25 \mathrm{~cm}$ of sediment and $15 \mathrm{~cm}$ of water were included. In the liners with mollusks, one individual per core was collected. PVC stoppers provided with 2 O-rings were inserted in the liner bottom and undisturbed intact cores with clear water phase were retrieved. Additional sediment cores devoid of mollusks ( $n=3$, i.d. $5 \mathrm{~cm}$, height $30 \mathrm{~cm}$ ) were collected for sediment characterization: density, porosity, organic matter, concentrations of ammonium $\left(\mathrm{NH}_{4}^{+}\right)$, soluble reactive phosphorus (SRP) and reactive silica $\left(\mathrm{SiO}_{2}\right)$ in pore water and for potential microbial activities. Besides

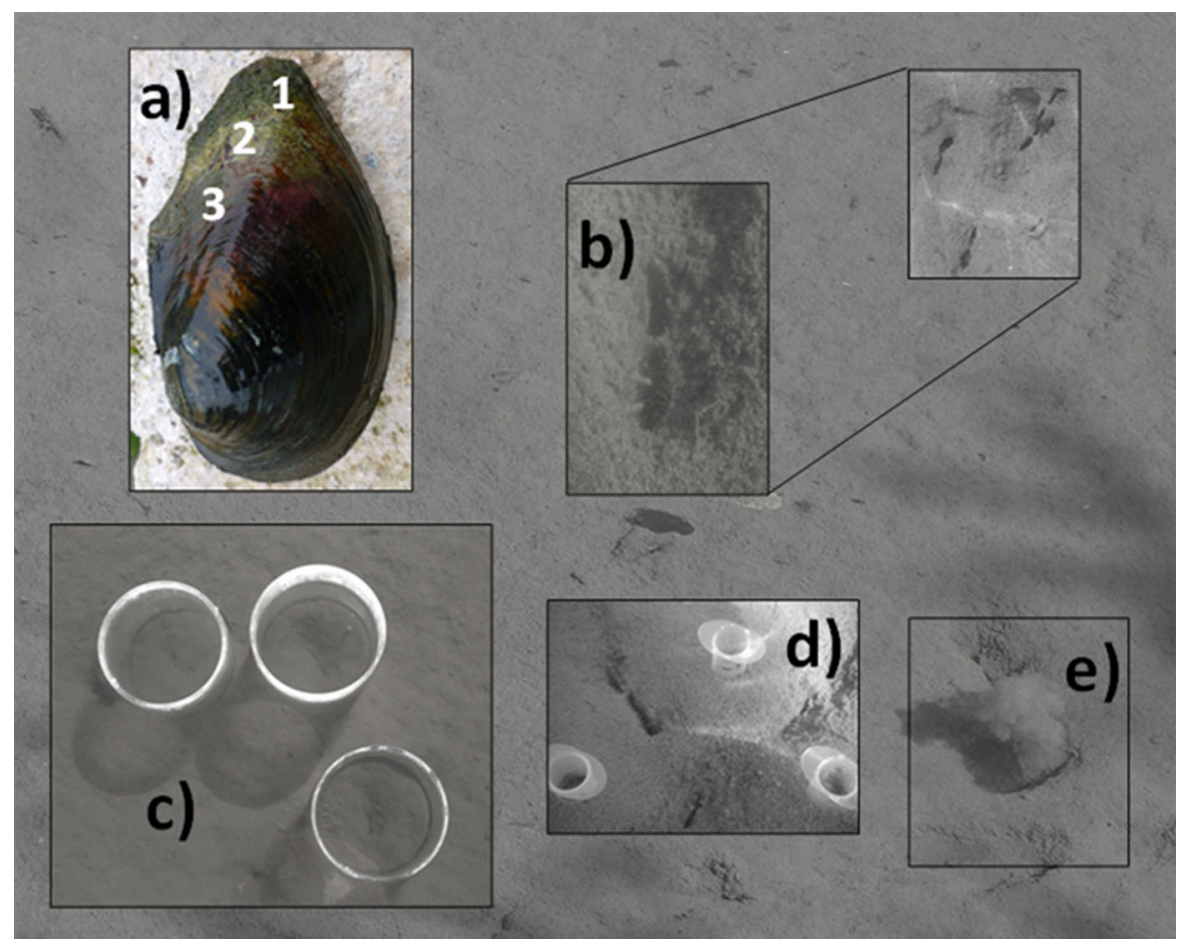

Fig. 1 Surface sediment of the canal under investigation, where $S$. woodiana individuals (a) were clearly visible through their siphons (b), allowing sampling undisturbed sediment cores with and without bivalves (c). The upper sediment layer was collected via cut-off syringes inserted vertically by hand in the sediment to extract Chl $a$ in the proximity of siphons and $>1 \mathrm{~m}$ far from them (d). Recovered organisms had epiphytic algae (1), growing in the upper extreme of the shell, as well as biofilms of whitish (2) and purple bacteria (3). Sediments around $S$. woodiana were frequently resuspended by the bivalve (e) 
the individuals within the incubation cores, bivalves of different sizes were also collected by hand for metabolic measurements and were stored in a tank with in situ aerated water. Nearly $200 \mathrm{~L}$ of water was collected from the canal for preincubation and incubation procedures.

Sedimentary features and potential microbial activities

The upper $10 \mathrm{~cm}$ vertical sediment horizon was extruded with a piston from each of the $5 \mathrm{~cm}$ i.d. cores and homogenized. Bulk density was determined as the ratio between wet weight and volume $(5 \mathrm{~mL})$ of sediment $(n=3)$; the sediment was collected by means of a cut-off 5-mL syringe filled with the sediment homogenate. The water content was determined after desiccation of the same fresh sediment volume at $60{ }^{\circ} \mathrm{C}$ until constant weight; porosity was calculated as the ratio between the volume of water and that of fresh sediment. Organic matter content (OM) was measured as percentage of weight loss by ignition $\left(450{ }^{\circ} \mathrm{C}, 2 \mathrm{~h}\right)$ from dried, powdered sediment. In addition, nearly $20 \mathrm{~mL}$ of fresh sediment $(n=3)$ was centrifuged to extract pore water that was analyzed spectrophotometrically for $\mathrm{NH}_{4}^{+}$, SRP and $\mathrm{SiO}_{2}$ interstitial concentration as detailed below. These concentrations reflect the average along the upper $10 \mathrm{~cm}$ horizon. Chlorophyll (Chl a) was extracted from about $1 \mathrm{~g}$ of fresh sediment taken in situ in the proximity of siphons $(n=6)$ and $>1 \mathrm{~m}$ far from them $(n=6)$. The upper sediment layer $(0.5 \mathrm{~cm})$ was collected via cutoff syringes inserted vertically by hand in the sediment (Fig. 1). Fresh sediments were immediately transferred in vials containing $10 \mathrm{~mL}$ of $90 \%$ acetone and stored $24 \mathrm{~h}$ in the dark. The extracted chlorophyll was thereafter determined after centrifugation and filtration according to Lorenzen (1967).

Two $\mathrm{mL}$ of surface sediments from the suboxic zone (from the $0.5-1.5 \mathrm{~cm}$ horizon, $n=18$ ) was collected and transferred to $12-\mathrm{mL}$ glass vials, containing a glass bead. Six treatments, each with three replicates, were then applied. The vials were amended with: (1) $\mathrm{NO}_{3}^{-}$-free water; (2) $\mathrm{NO}_{3}^{-}$-free water and $S$. woodiana feces and pseudofeces; (3) $20 \mu \mathrm{M}^{15} \mathrm{NO}_{3}^{-}$water; (4) $20 \mu \mathrm{M}^{15} \mathrm{NO}_{3}^{-}$water and $S$. woodiana feces and pseudofeces; (5) $\mathrm{NO}_{3}^{-}$-free and $10 \mu \mathrm{M}{ }^{15} \mathrm{NH}_{4}^{+}$water and (6) $20 \mu \mathrm{M}{ }^{15} \mathrm{NH}_{4}^{+}$and
$20 \mu \mathrm{M}{ }^{14} \mathrm{NO}_{3}^{-}$water. The 6 treatments targeted potential $\mathrm{CH}_{4}$ production in the absence (1) and presence (2) of bivalve fecal material, potential denitrification in the absence (3) and presence (4) of bivalve fecal material, and the occurrence of anammox (5 and 6), respectively. The bivalve fecal material was collected with a 50-mL syringe from the bottom of a large beaker containing in situ water and bivalves, without sediment. The collected material was concentrated via centrifugation and supernatant removal; thereafter, $1 \mathrm{~mL}$ of the fecal material, corresponding to $0.2 \mathrm{~g}_{\mathrm{DW}}$, was added to each Exetainer. All added water was previously bubbled with $\mathrm{N}_{2}$ to remove any $\mathrm{O}_{2}$ and $\mathrm{CH}_{4}$ traces. Once filled, all vials were capped leaving no air bubbles, transferred into a rotating shaker and incubated for $24 \mathrm{~h}$ in the dark at $20^{\circ} \mathrm{C}$; afterward, $200 \mu \mathrm{L} 7 \mathrm{M} \mathrm{ZnCl} 2$ was added to the samples to inhibit microbial activity at the end of incubation. ${ }^{14} \mathrm{~N}^{15} \mathrm{~N}$ and ${ }^{15} \mathrm{~N}^{15} \mathrm{~N}$ abundance in $\mathrm{N}_{2}$ and dissolved $\mathrm{CH}_{4}$ were analyzed by membrane inlet mass spectrometry (MIMS, Bay instruments, USA). More details on these assays are reported in Thamdrup and Dalsgaard (2002).

\section{Measurement of benthic fluxes and S. woodiana} metabolism

Once collected, water, sediment samples and bivalves were transferred to the laboratory within $1 \mathrm{~h}$. Cores were submersed with the top open in a large incubation tank containing well-mixed and aerated in situ water maintained at the ambient temperature $\left(20^{\circ} \mathrm{C}\right)$. The day after the sampling all cores were incubated in the dark for dissolved gas and nutrient flux measurements (Dalsgaard et al. 2000). Incubations started when a gas-tight lid with a sampling port and a compensation valve was positioned on the liners top. The water inside each liner was gently mixed by a small aquarium pump, which provided a minimum flow $\left(1 \mathrm{~L} \mathrm{~min}^{-1}\right)$ to avoid stagnation and to guarantee homogeneous conditions within the cores, but excluding sediment resuspension. Incubations lasted $2 \mathrm{~h}$; water samples (nearly $80 \mathrm{~mL}$ ) were collected at the beginning and at the end of the incubation and analyzed for dissolved gas $\left(\mathrm{O}_{2}, \mathrm{CH}_{4}, \mathrm{~N}_{2}\right.$ and $\left.\mathrm{TCO}_{2}\right)$ and nutrients $\left(\mathrm{NH}_{4}^{+}, \mathrm{NO}_{2}^{-}, \mathrm{NO}_{3}^{-}, \mathrm{SiO}_{2}\right.$ and $\left.\mathrm{SRP}\right)$. Samples for $\mathrm{O}_{2}, \mathrm{CH}_{4}, \mathrm{~N}_{2}$ and $\mathrm{TCO}_{2}$ were transferred to 12-mL Exetainers (Labco, UK); with the exception of $\mathrm{TCO}_{2}$ they were poisoned with $100 \mu \mathrm{L}$ of $7 \mathrm{M} \mathrm{ZnCl}_{2}$. 
Dissolved $\mathrm{O}_{2}$ was measured by means of polarography with a microelectrode (Unisense, Denmark). Dissolved $\mathrm{CH}_{4}$ and $\mathrm{N}_{2}$ were measured via MIMS. $\mathrm{TCO}_{2}$ was measured via 6 end points $0.1 \mathrm{~N} \mathrm{HCl}$ titration (Anderson et al. 1986). Samples for the determination of inorganic forms of $\mathrm{N}$ and $\mathrm{Si}$ were filtered through Whatman $\mathrm{GF} / \mathrm{F}$ glass fiber filters, transferred into 20-mL plastic vials and analyzed with standard spectrophotometric techniques (Golterman et al. 1978; Bower and Holm-Hansen 1980). Samples for SRP determination were filtered and transferred into glass vials and analyzed spectrophotometrically (Valderrama 1977). Fluxes were calculated according to the equation below.

Flux $x=\frac{\left([x]_{f}-[x]_{i}\right) \times V}{A \times t}$

where $[x]_{f}$ and $[x]_{i}$, expressed in $\mu \mathrm{M}$ or $\mathrm{mM}$, are the concentrations of the solute $x$ at the end and at the start of the incubation, respectively, $V(\mathrm{~L})$ is the volume of the core water phase, $A\left(\mathrm{~m}^{2}\right)$ is the area of the sediment and $t(\mathrm{~h})$ is the incubation time.

The top lids were thereafter removed and the water in the tank replaced with fresh in situ water. In the afternoon, a sequential incubation was performed aiming at the measurement of denitrification rates with the isotope pairing technique (IPT, Nielsen 1992). Briefly, $10 \mathrm{~mL}$ of a $15 \mathrm{mM}^{15} \mathrm{NO}_{3}^{-}$stock solution was added to the water phase of each liner to have a final concentration of labeled nitrate of $30 \mu \mathrm{M}$. The top lids were then positioned and the cores were incubated in the dark for $2 \mathrm{~h}$. At the end of the incubation, the lids were removed and the whole sediment and water phase gently slurried, subsampled, transferred in Exetainers and poisoned with $200 \mu \mathrm{L}$ of $7 \mathrm{M} \mathrm{ZnCl}_{2}$ for labeled $\mathrm{N}_{2}$ analysis. The latter was performed within 1 week by means of MIMS. At the end of the procedure, the cores were sieved through a $0.5 \mathrm{~mm}$ mesh in order to visual-check for the occurrence of other macrofauna and to recover the bivalves. The revised version of the IPT was not used at the sampling site as sediment slurries demonstrated the absence of anammox. The rates of denitrification were calculated according to the equations and assumptions of Nielsen (1992): $D_{15}=\mathrm{p}\left({ }^{15} \mathrm{~N}^{14} \mathrm{~N}\right)+2 \mathrm{p}\left({ }^{15} \mathrm{~N}^{15} \mathrm{~N}\right)$ and $D_{14}$ $=\mathrm{p}\left({ }^{15} \mathrm{~N}^{14} \mathrm{~N}\right)+2 \mathrm{p}\left({ }^{14} \mathrm{~N}^{14} \mathrm{~N}\right)$, where $D_{15}$ and $D_{14}$ $=$ rates of denitrification based on ${ }^{15} \mathrm{NO}_{3}^{-}$and ${ }^{14} \mathrm{NO}_{3}^{-}$, respectively; and $\mathrm{p}\left({ }^{14} \mathrm{~N}^{14} \mathrm{~N}\right), \mathrm{p}\left({ }^{15} \mathrm{~N}^{14} \mathrm{~N}\right)$ and $\mathrm{p}\left({ }^{15} \mathrm{~N}^{15} \mathrm{~N}\right)=$ rates of production of labeled and unlabeled $\mathrm{N}_{2}$ species. Because the $\mathrm{p}\left({ }^{14} \mathrm{~N}^{14} \mathrm{~N}\right)$ cannot be readily measured, estimation of $D_{14}$ was obtained from: $D_{14}=D_{15} \times p\left({ }^{15} \mathrm{~N}^{14} \mathrm{~N}\right) / 2 \mathrm{p}\left({ }^{15} \mathrm{~N}^{15} \mathrm{~N}\right)$. The proportion of $D_{14}$ supported by unlabeled $\mathrm{NO}_{3}^{-}$from the water column $\left(D_{\mathrm{W}}\right)$ was calculated from: $D_{\mathrm{W}}=$ $D_{15} \times f /(1-f)$, where $f=$ mole fraction of ${ }^{14} \mathrm{NO}_{3}^{-}$ in the water column. The coupled nitrification-denitrification $\left(D_{\mathrm{N}}\right)$ was calculated by difference as: $D_{\mathrm{N}}=D_{14}-D_{\mathrm{W}}$.

Individuals of $S$. woodiana recovered from the cores were then gently brushed to remove biofilm growing on the shell and individually incubated in the dark to analyze gas and nutrient exchange between the mollusks and the water phase. Organisms were incubated in the same set of cores, but in the absence of sediment. The procedure was exactly the same described above. All incubated individuals were characterized for wet weight (WW) and for shell-free dry weight (SFDW), after drying the soft tissue at $60{ }^{\circ} \mathrm{C}$ to a constant weight.

Statistical analyses

The nonparametric Mann-Whitney $U$ test was used to test differences between the concentration of $\mathrm{Chl}$ $a$ close to and far from the siphons of $S$. woodiana and between potential denitrification and $\mathrm{CH}_{4}$ production activities in sediments with and without $S$. woodiana feces. The same test was used to investigate differences between diffusive benthic fluxes measured in the three conditions: (a) sediment alone $(S)$ versus sediment with $S$. woodiana $(S+A)$, (b) $S+A$ versus $S$. woodiana alone $(A)$ and (c) $S$ versus $A$. Fluxes measured in $S+A$ and $A$ were related to the shell-free dry biomass of the incubated organisms with a simple linear regression analysis. Differences between slopes were tested by Student's $t$ test. Statistical significance was set at $p<0.05$. Statistical analyses were performed with Sigma Plot 12.0.

\section{Results}

Sediment features

Chlorophyll $a$ concentration in the upper sediment horizon revealed a large availability of benthic labile carbon associated with algal material. Sedimentary 
Chl $a$ tended to be higher close to $S$. woodiana siphons than far from mollusks $(217 \pm 13$ vs $197 \pm 7 \mathrm{mg} \mathrm{Chl}$ $a \mathrm{~m}^{-2}$, average $\pm \mathrm{SE}$ ) but differences were not statistically significant (Mann-Whitney $U$ test, $p>0.05$, Table 1). The $0-10 \mathrm{~cm}$ sediment profile was extremely fluffy, displaying low density, high porosity and elevated content of OM (Table 1). Pore water analysis of inorganic nutrients suggested high availability of $\mathrm{NH}_{4}^{+}$and $\mathrm{SiO}_{2}$, with comparable concentrations, and scarce mobility of SRP, likely trapped in the organic matrix (Table 1).

Sediments displayed elevated rates of denitrification potential, with the process not saturated even at $200 \mu \mathrm{M}{ }^{15} \mathrm{NO}_{3}^{-}$concentration (data not shown). Results from slurry measurements (Table 2) suggested that the addition of $S$. woodiana feces did not stimulate the production of $\mathrm{N}_{2}$ via denitrification and that of $\mathrm{CH}_{4}$ compared to unamended sediment. Measured rates were in fact not statistically different (Mann-Whitney $U$ test, $p>0.05$, Table 2). ${ }^{29} \mathrm{~N}_{2}$ was not detected in any of the treatments, including those with ${ }^{15} \mathrm{NH}_{4}^{+}$, suggesting that anammox was unimportant in $\mathrm{N}_{2}$ production at the study site and supporting the application of the IPT to determine denitrification rates.

\section{S. woodiana features}

The density of $S$. woodiana at the study area was 6.0 $\left( \pm 1.8\right.$; SE) ind $\mathrm{m}^{-2}$; among bivalves we found a few

Table 1 Sedimentary features at the sampling site

\begin{tabular}{lc}
\hline Features & Average $\pm \mathrm{SE}$ \\
\hline $\mathrm{Chl} a\left(\mathrm{mg} \mathrm{m}^{-2}\right)$ & $207 \pm 7$ \\
Density $\left(\mathrm{g} \mathrm{cm}^{-3}\right)$ & $1.04 \pm 0.02$ \\
Porosity $(\%)$ & $0.94 \pm 0.02$ \\
$\mathrm{OM}(\%)$ & $24.1 \pm 0.2$ \\
Pore water & \\
$\mathrm{NH}_{4}^{+}(\mu \mathrm{M})$ & $211 \pm 14$ \\
$\mathrm{SiO}_{2}(\mu \mathrm{M})$ & $163 \pm 15$ \\
$\mathrm{SRP}(\mu \mathrm{M})$ & $0.5 \pm 0.1$ \\
\hline
\end{tabular}

Chlorophyll $a(\mathrm{Chl} a)$ was extracted from the upper $1 \mathrm{~cm}$ horizon, close $(n=6)$ and far $(n=6)$ from the bivalve siphons, but as differences were not significant data were pooled. All the remaining variables were measured on integrated sediment samples $(n=3)$, along the upper $0-10 \mathrm{~cm}$ vertical horizon. Average values \pm standard errors are reported individuals of Corbicula spp. $\left(<1 \mathrm{~m}^{-2}\right)$. Recovered macrofauna included also chironomid larvae and oligochaetes, among which the non-native Sparganophilus tamesis. However, their occurrence was sporadic likely due to the sampling season or to the absence of macrophytes (Rota et al. 2014). We cannot exclude the occurrence of other taxa as our macrofauna analysis was not exhaustive and mainly targeting potentially relevant bioturbating organisms besides $S$. woodiana. The population of $S$. woodiana was composed mostly of large individuals, with an average wet weight of $283\left( \pm 33\right.$; SE) $\mathrm{g}_{\mathrm{wW}}$ ind $^{-1}$, corresponding to a shell-free dry weight of $12.9( \pm 1.5$; SE) g g ind $^{-1}$. The upper portion of the bivalve outer shell was colonized by a thick layer of microalgae while the rest was colonized by bacterial biofilms (Fig. 1).

Benthic respiration and bivalve metabolism

The presence of the bivalve affected both aerobic and anaerobic benthic respiration. All the cores containing sediments with bivalves had one single large individual and displayed significantly higher $\mathrm{O}_{2}$ consumption, $\mathrm{TCO}_{2}, \mathrm{~N}_{2}$ and $\mathrm{CH}_{4}$ production as compared to sediments without $S$. woodiana (Mann-Whitney $U$ test, $p<0.01$, Fig. 2). Benthic $\mathrm{O}_{2}$ demand measured in $\mathrm{S}+\mathrm{A}$ overlapped the rate measured in $\mathrm{A}$ and it was nearly 3.6-fold higher than the rate measured in $\mathrm{S}$ (Fig. 2). Similar results were obtained for $\mathrm{TCO}_{2}$ production that was significantly higher in $\mathrm{S}+\mathrm{A}$ compared to $\mathrm{S}$ and not significantly different in $\mathrm{S}+\mathrm{A}$ and A (Mann-Whitney $U$ test, $p<0.01$ and $p=0.3$, respectively, Fig. 2). These results suggest that most of the increase in $\mathrm{O}_{2}$ consumption and $\mathrm{TCO}_{2}$ production was due to the mollusk metabolism.

The effect of $\mathrm{S}$. woodiana on $\mathrm{N}_{2}$ and $\mathrm{CH}_{4}$ fluxes was also significant, but not related to the mollusk metabolism and therefore not direct (Fig. 2). Rates of total denitrification $\left(D_{\mathrm{N}}+D_{\mathrm{W}}\right)$ measured via the IPT were significantly higher, by a factor of 2 , in $\mathrm{S}+\mathrm{A}$ than in $\mathrm{S}$ (Mann-Whitney $U$ test, $p<0.001$, Fig. 2). The presence of the bivalve stimulated the reduction both of $\mathrm{NO}_{3}^{-}$diffusing to the anoxic sediment from the water column $\left(D_{\mathrm{W}}\right)$ and of the $\mathrm{NO}_{3}^{-}$produced via nitrification $\left(D_{\mathrm{N}}\right)$, but only differences between $D_{\mathrm{N}}$ in $\mathrm{S}+\mathrm{A}$ and in $\mathrm{S}$ were significant (Mann-Whitney $U$ test, $p<0.05$, Fig. 2). Net $\mathrm{N}_{2}$ fluxes were positive, suggesting the dominance of denitrification over $\mathrm{N}$-fixation at the study site 
Table 2 Results from anoxic incubation of sediment slurries added with ${ }^{14} \mathrm{~N}$ nitrate-free water (control), ${ }^{14} \mathrm{~N}$ nitrate-free water and $S$. woodiana feces and various combinations of labeled and unlabeled $\mathrm{NO}_{3}^{-}$and $\mathrm{NH}_{4}^{+}$and biodeposits

\begin{tabular}{llll}
\hline Treatment & $\begin{array}{l}\text { Denitrification } \\
\left(\mathrm{nM} \mathrm{N} \mathrm{h} \mathrm{mL}^{-1}\right)\end{array}$ & $\begin{array}{l}\text { Anammox } \\
\left(\mathrm{nM} \mathrm{N} \mathrm{h}^{-1} \mathrm{~mL}^{-1}\right)\end{array}$ & $\begin{array}{l}\text { Methanogenesis } \\
\left(\mathrm{nM} \mathrm{C} \mathrm{h}^{-1} \mathrm{~mL}^{-1}\right)\end{array}$ \\
\hline Control & - & - & $53.6 \pm 8.2$ \\
$\mathrm{H}_{2} \mathrm{O}+$ feces & - & - & $68.7 \pm 6.3$ \\
$20 \mathrm{mM}{ }^{15} \mathrm{NO}_{3}^{-}$ & $8.5 \pm 4.5$ & $0.0 \pm 0.0$ & $65.8 \pm 5.9$ \\
$20 \mathrm{mM}^{15} \mathrm{NO}_{3}^{-}+$feces & $7.6 \pm 3.8$ & $0.0 \pm 0.0$ & $66.8 \pm 3.7$ \\
$20 \mathrm{mM}^{15} \mathrm{NH}_{4}^{+}+20 \mathrm{mM}{ }^{14} \mathrm{NO}_{3}^{-}$ & - & $0.0 \pm 0.0$ & $64.5 \pm 2.8$ \\
$10 \mathrm{mM}{ }^{15} \mathrm{NH}_{4}^{+}$ & - & $0.0 \pm 0.0$ & $88.5 \pm 7.3$ \\
\hline
\end{tabular}

See the text for more details on the 6 treatments. Average values \pm standard errors are reported $(n=3)$

Fig. 2 Dark benthic fluxes of dissolved oxygen $\left(\mathrm{O}_{2}\right)$, total inorganic carbon $\left(\mathrm{TCO}_{2}\right)$, dissolved molecular nitrogen $\left(\mathrm{N}_{2}\right)$ and methane $\left(\mathrm{CH}_{4}\right)$ measured in incubations of bare sediments ( $\mathrm{S}, n=11)$, sediments with $S$. woodiana $(\mathrm{S}+\mathrm{A}, n=13)$ and single individuals of the bivalve (A, $n=13$ ). Rates of denitrification of water column $\mathrm{NO}_{3}^{-}\left(D_{\mathrm{W}}\right)$ and of coupled nitrificationdenitrification $\left(D_{\mathrm{N}}\right)$ were measured with the isotope pairing technique (IPT) only in $\mathrm{S}$ and $\mathrm{S}+\mathrm{A}$.

Averages \pm standard errors are reported. Different letters above bars indicate statistical differences between fluxes ${ }^{*} p<0.05$, $* * p<0.01$ and $* * * p<0.001)$
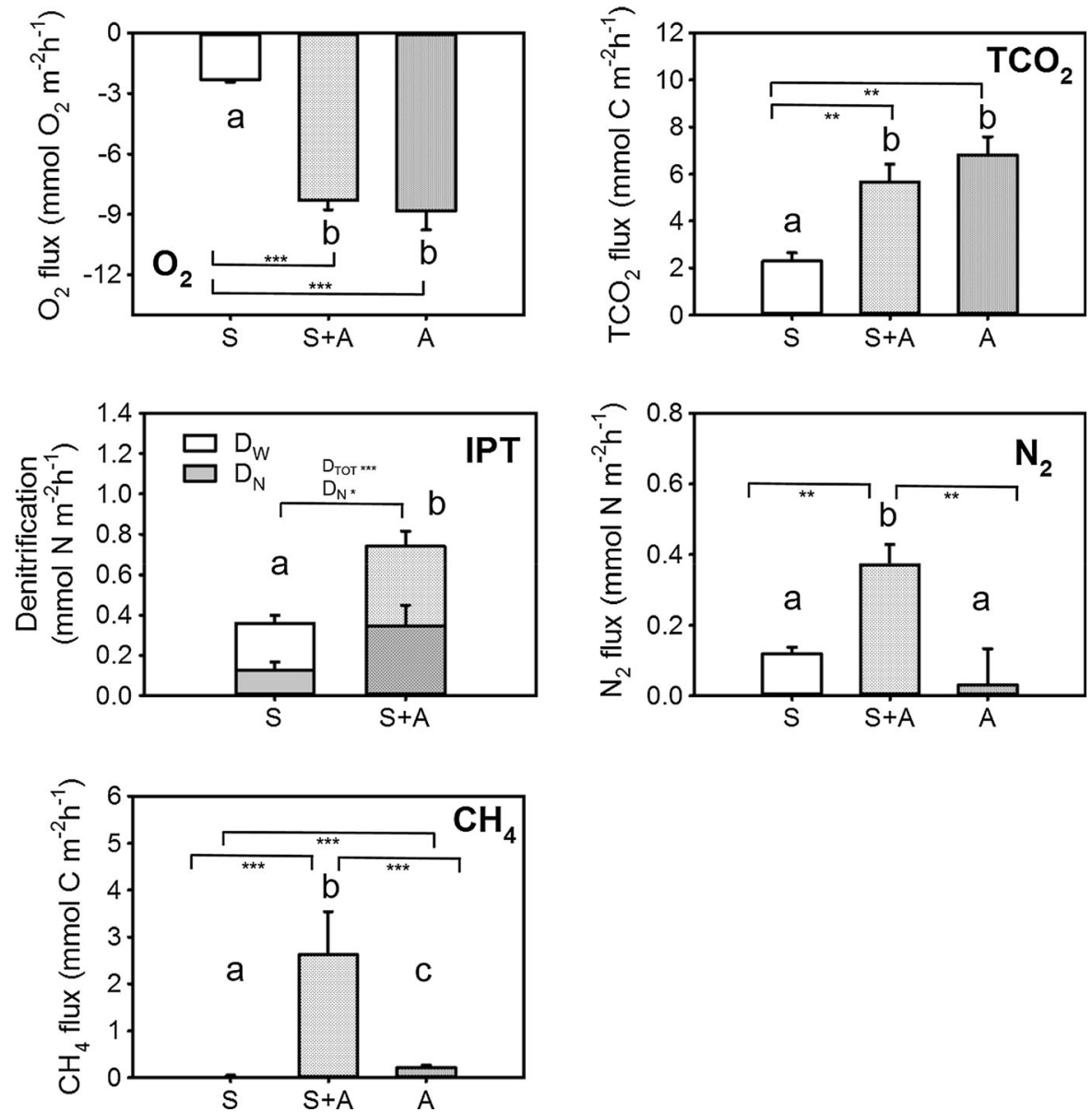

(Fig. 2). However, rates were lower as compared to those measured with the IPT, due to methodological issues or to the occurrence of some $\mathrm{N}$-fixation. Net $\mathrm{N}_{2}$ efflux was enhanced by a factor of $3.1 \mathrm{in} \mathrm{S}+\mathrm{A}$ versus
$S$ cores (Mann-Whitney $U$ test, $p<0.01$ ). Diffusive $\mathrm{CH}_{4}$ efflux increased by a factor of 94 , from 0.03 $( \pm 0.90, \mathrm{SE})$ to $2.60( \pm 0.01, \mathrm{SE}) \mathrm{mmol} \mathrm{m} \mathrm{m}^{-2} \mathrm{~h}^{-1}$ measured in $\mathrm{S}$ and $\mathrm{S}+\mathrm{A}$, respectively (Mann- 
Table 3 Linear regression between benthic fluxes ( $S$ and $S+A$ ) and the shell-free dry biomass of $S$. woodiana recovered from incubated cores ( $S$ and $S+A$ vs dry biomass) $(n=24)$, linear regression between the mollusk alone fluxes
(A) and the shell-free dry biomass of $S$. woodiana ( $A$ vs dry biomass) $(n=21)$ and results from a t test ( $p$ value) comparing the two slopes

\begin{tabular}{|c|c|c|c|c|c|c|c|}
\hline \multirow{3}{*}{$\begin{array}{l}\text { Measure } \\
\mathrm{O}_{2}\end{array}$} & \multicolumn{3}{|c|}{$\begin{array}{l}\text { Rates measured in } \\
S \text { and } S+A \text { versus dry biomass }\end{array}$} & \multicolumn{3}{|c|}{$\begin{array}{l}\text { Rates measured in } \\
A \text { versus dry biomass }\end{array}$} & \multirow{2}{*}{$\begin{array}{l}\begin{array}{l}\text { Slope comparison } \\
\text { (two-tailed } p \text { value) }\end{array} \\
p=0.201\end{array}$} \\
\hline & Slope & $-0.28 \pm 0.03$ & $p \leq 0.001$ & Slope & $-0.40 \pm 0.09$ & $p \leq 0.001$ & \\
\hline & Intercept & $-2.82 \pm 0.44$ & $p \leq 0.001$ & Intercept & 0 & & \\
\hline \multirow[t]{2}{*}{$\mathrm{TCO}_{2}$} & Slope & $0.16 \pm 0.04$ & $p \leq 0.01$ & Slope & $0.41 \pm 0.56$ & $p=0.437$ & n.d. \\
\hline & Intercept & $2.56 \pm 0.67$ & $p \leq 0.001$ & Intercept & 0 & & \\
\hline \multirow[t]{2}{*}{$\mathrm{N}_{2}$} & Slope & $9.89 \pm 3.48$ & $p \leq 0.01$ & Slope & $3.07 \pm 1.13$ & $p \leq 0.05$ & $p=0.069$ \\
\hline & Intercept & $155.62 \pm 50.77$ & $p \leq 0.01$ & Intercept & 0 & & \\
\hline \multirow[t]{2}{*}{$\mathrm{CH}_{4}$} & Slope & $101.89 \pm 48.24$ & $p \leq 0.05$ & Slope & $12.91 \pm 5.67$ & $p \leq 0.05$ & $p=0.080$ \\
\hline & Intercept & $396.27 \pm 689.23$ & $p=0.571$ & Intercept & 0 & & \\
\hline \multirow[t]{2}{*}{$\mathrm{NH}_{4}^{+}$} & Slope & $28.86 \pm 3.77$ & $p \leq 0.001$ & Slope & $32.37 \pm 9.58$ & $p \leq 0.01$ & $p=0.730$ \\
\hline & Intercept & $12.21 \pm 54.77$ & $p=0.826$ & Intercept & 0 & & \\
\hline \multirow[t]{2}{*}{$\mathrm{NO}_{3}^{-}$} & Slope & $-9.15 \pm 11.02$ & $p=0.417$ & Slope & $-4.80 \pm 3.75$ & $p=0.220$ & n.d. \\
\hline & Intercept & $-104.33 \pm 166.75$ & $p \leq 0.05$ & Intercept & 0 & & \\
\hline \multirow[t]{2}{*}{$\mathrm{NO}_{2}^{-}$} & Slope & $2.79 \pm 1.09$ & $p \leq 0.05$ & Slope & $0.95 \pm 1.35$ & $p=0.487$ & n.d. \\
\hline & Intercept & $-25.75 \pm 15.33$ & $p=0.112$ & Intercept & 0 & & \\
\hline \multirow[t]{2}{*}{ DIN } & Slope & $19.43 \pm 9.08$ & $p \leq 0.05$ & Slope & $30.65 \pm 13.55$ & $p \leq 0.05$ & $p=0.481$ \\
\hline & Intercept & $-95.59 \pm 134.75$ & $p=0.478$ & Intercept & 0 & & \\
\hline \multirow[t]{2}{*}{ SRP } & Slope & $0.87 \pm 0.42$ & $p \leq 0.05$ & Slope & $1.32 \pm 0.48$ & $p \leq 0.01$ & $p=0.487$ \\
\hline & Intercept & $-3.94 \pm 5.97$ & $p=0.517$ & Intercept & 0 & & \\
\hline \multirow[t]{2}{*}{$\mathrm{SiO}_{2}$} & Slope & $13.51 \pm 7.22$ & $p=0.075$ & Slope & $7.16 \pm 6.44$ & $p=0.281$ & n.d. \\
\hline & Intercept & $-29.48 \pm 105.25$ & $p=0.782$ & Intercept & 0 & & \\
\hline
\end{tabular}

When one of the two slopes was not significantly different from zero we did not perform the test (n.d.). Units for $\mathrm{O}_{2}$, $\mathrm{TCO}_{2}$ slope and intercept are $\mathrm{mmol} \mathrm{g}_{\mathrm{SFDW}}^{-1} \mathrm{~h}^{-1}$ and $\mathrm{mmol} \mathrm{m}^{-2} \mathrm{~h}^{-1}$, respectively. For all remaining parameters slope and intercept units are $\mu \mathrm{mol} \mathrm{g}_{\mathrm{SFDW}}^{-1} \mathrm{~h}^{-1}$ and $\mu \mathrm{mol} \mathrm{m} \mathrm{m}^{-2} \mathrm{~h}^{-1}$, respectively

Whitney $U$ test, $p<0.001$, Fig. 2). Rates of $\mathrm{N}_{2}$ production in incubations with $S$. woodiana alone revealed that the contribution of the mollusk to the flux measured in $\mathrm{S}+\mathrm{A}$ was small, as rates in $\mathrm{S}$ and $\mathrm{A}$ were similar (Mann-Whitney $U$ test, $p>0.05$ ) (Fig. 2). Fluxes of $\mathrm{CH}_{4}$ in incubations with $\mathrm{S}$. woodiana alone were statistically different from fluxes measured in $\mathrm{S}$ and $\mathrm{S}+\mathrm{A}$ (Mann-Whitney $U$ test, $p<0.01$ and $p<0.001$, respectively).

Oxygen demand and $\mathrm{TCO}_{2}, \mathrm{~N}_{2}$ and $\mathrm{CH}_{4}$ production measured in $\mathrm{S}+\mathrm{A}$ increased linearly with the shellfree dry weight of $S$. woodiana recovered from each core (Table 3). Also $\mathrm{O}_{2}$ demand measured in A increased linearly with the shell-free dry biomass of the incubated organisms, with a slope not statistically different from that calculated in sediments with $S$. woodiana. On the contrary, for $\mathrm{CH}_{4}$ and $\mathrm{N}_{2}$ the comparison between the slopes was close to significant (Table 3).
To calculate the average benthic respiration rates in the study area, we gave appropriate weights to measured fluxes (nearly 80 and $20 \%$ to $S$ and $S+A$ rates, respectively). Such weights were obtained downscaling fluxes measured in the $S+A$ cores, where bivalve density was nearly 32 ind $\mathrm{m}^{-2}$ ( 1 ind per core with a core surface of $314 \mathrm{~cm}^{2}$ ) to the in situ $S$. woodiana density which was nearly 5 times lower $\left(6\right.$ ind $\left.\mathrm{m}^{-2}\right)$. The weighted average $\mathrm{O}_{2}, \mathrm{TCO}_{2}, \mathrm{~N}_{2}$ and $\mathrm{CH}_{4}$ fluxes in the study area were $3.51 \pm 0.14,2.97 \pm 0.27,0.17 \pm 0.02$ and $0.55 \pm 0.18$ (all averages $\pm \mathrm{SE}$ ) $\mathrm{mmol} \mathrm{m}^{-2} \mathrm{~h}^{-1}$, respectively, with a bivalve biomass of $95( \pm 10$; SE) $g_{\text {SFDW }} \mathrm{m}^{-2}$. Such values are 1.5-, 1.3-, 1.4- and 19.7-fold higher than those measured in sediments without mollusks and suggest a similar stimulation of aerobic respiration and denitrification by the bivalve and a much higher stimulation of methanogenesis. 
Benthic nutrient fluxes and bivalve excretion

Bare sediments were sinks for dissolved nutrients while sediments with $S$. woodiana recycled large amounts of $\mathrm{NH}_{4}^{+}, \mathrm{SiO}_{2}$ and SRP to the water column (Fig. 3). The fluxes of $\mathrm{NH}_{4}^{+}$and $\mathrm{SiO}_{2}$ measured in $S+A$ and $A$ were significantly different from those measured in $S$ (Mann-Whitney $U$ test, $p<0.01$ ). In the presence of $S$. woodiana, the fluxes of SRP were also reversed, but due to small scale high variability the difference between the conditions $S+A$ and $S$ was not significant. In the incubations of $S$. woodiana alone, excretion rates of $\mathrm{NH}_{4}^{+}, \mathrm{SiO}_{2}$ and SRP overlapped fluxes measured in $S+A$ cores (Fig. 3).

The fluxes of nitrite were low if compared to those of $\mathrm{NH}_{4}^{+}$and $\mathrm{NO}_{3}^{-}$in both $S$ and $S+A$, but rates
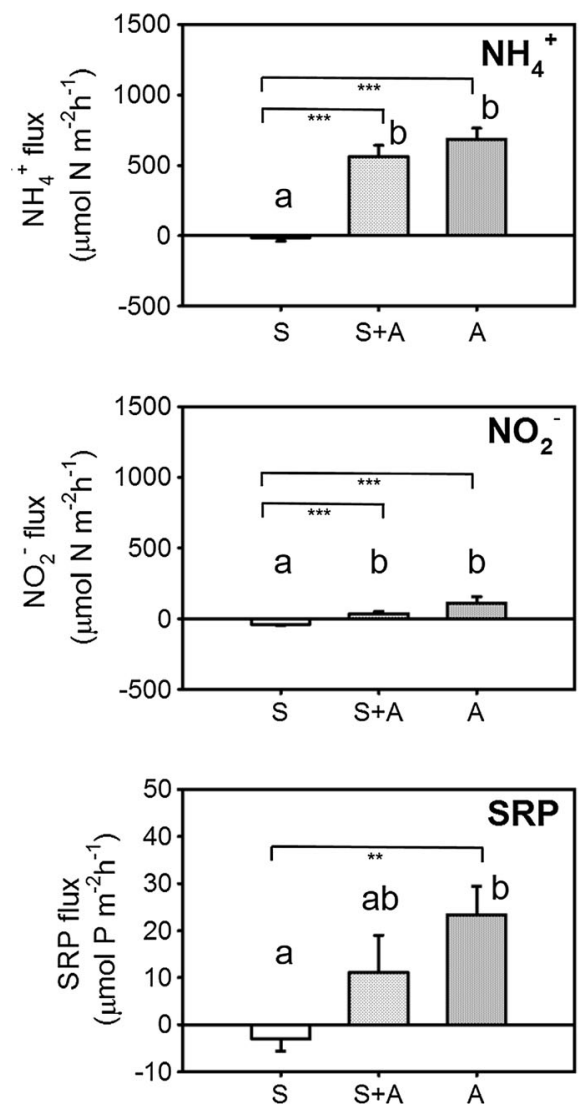

Fig. 3 Dark benthic fluxes of ammonium $\left(\mathrm{NH}_{4}^{+}\right)$, nitrate $\left(\mathrm{NO}_{3}^{-}\right)$, nitrite $\left(\mathrm{NO}_{2}^{-}\right)$, dissolved inorganic nitrogen (DIN), soluble reactive phosphorus (SRP) and dissolved reactive silica $\left(\mathrm{SiO}_{2}\right)$ measured in incubations of bare sediments $(\mathrm{S}, n=11)$, sediments with $S$. woodiana $(\mathrm{S}+\mathrm{A}, n=13)$ and single measured in the two conditions were statistically different (Mann-Whitney $U$ test, $p<0.01$ ). The flux of $\mathrm{NO}_{3}^{-}$had a different trend if compared with the other dissolved nutrients, being net consumed in both $S$ and $S+A$, without a significant difference. A net release of $\mathrm{NO}_{3}^{-}$and $\mathrm{NO}_{2}^{-}$was measured in the incubation of $S$. woodiana alone.

The weighted average flux of $\mathrm{NH}_{4}^{+}, \mathrm{NO}_{3}^{-}, \mathrm{NO}_{2}^{-}$, DIN, SRP and $\mathrm{SiO}_{2}$ in the study area was $102 \pm 27$, $-159 \pm 124,-23 \pm 7,-78 \pm 95,-0.16 \pm 2.51$ and $-54 \pm 52$ (all averages $\pm \mathrm{SE}$ ) $\mu \mathrm{mol} \mathrm{m}{ }^{-2} \mathrm{~h}^{-1}$, respectively. The regressions between $\mathrm{NH}_{4}^{+}, \mathrm{NO}_{2}^{-}$, DIN and SRP fluxes measured in $S+A$ and the shellfree dry weight of $S$. woodiana recovered from incubated sediments were all significant while that of $\mathrm{SiO}_{2}$ was close to significant (Table 3). Similar
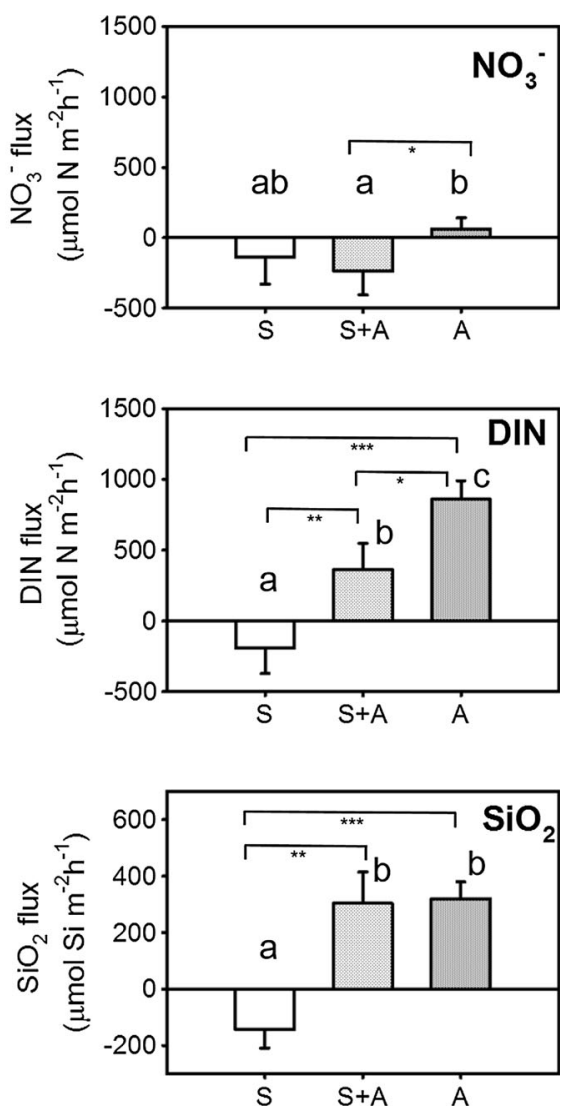

individuals of the bivalve (A, $n=13$ ). Averages \pm standard errors are reported. Different letters above bars indicate statistical differences between fluxes $(* p<0.05$, ** $p<0.01$ and $* * * p<0.001)$ 
outcomes were obtained with linear regressions between excreted nutrients ( $A$, mollusk alone incubation) and the shell-free dry biomass of the incubated individuals (Table 3). As the slopes of the two regressions were for most parameters not statistically different ( $p>0.05)$, we address the metabolism of $S$. woodiana as driving factor for benthic nutrient recycling.

On a molar basis, the stoichiometry of the dissolved mineral forms of $\mathrm{C}, \mathrm{N}, \mathrm{Si}$ and $\mathrm{P}$ regenerated to the water column in the presence of $S$. woodiana was 509:51:28:1. The C-to-N ratio $(\sim 10)$ suggests that the food source of $S$. woodiana has an elevated N content and it is probably labile organic matter. The N-to-Si ratio suggests that such pool is richer in $\mathrm{N}$ compared to $\mathrm{Si}$ and the N-to-P ratio suggests $\mathrm{P}$ limitation, even if most ingested $\mathrm{P}$ is generally released through feces and pseudofeces.

\section{Discussion}

Large, low-density bivalves affect benthic metabolism

Our results demonstrate that a few individuals of a large bivalve affect significantly benthic respiration rates (both aerobic and anaerobic paths, via their metabolism, biodeposition and bioturbation) and nutrient recycling $\left(\mathrm{NH}_{4}^{+}, \mathrm{SiO}_{2}\right.$ and $\mathrm{SRP}$, via direct excretion). The outcomes of this work conform to other studies targeting the effects of farmed or reefforming bivalves on sediment biogeochemistry, where similar results are reported (Bartoli et al. 2001; Nizzoli et al. 2006; Ruginis et al. 2014). However, only a few studies focused simultaneously on key benthic respiration paths and on the three nutrients $\mathrm{N}, \mathrm{Si}$ and $\mathrm{P}$ (Table 4). At the in situ density of 6 ind $\mathrm{m}^{-2}$, the bivalve stimulated the respiration of $\mathrm{O}_{2}$ and $\mathrm{NO}_{3}^{-}$and the production of $\mathrm{CH}_{4}$, reversed the fluxes of $\mathrm{NH}_{4}^{+}$and attenuated the sedimentary uptake of SRP and $\mathrm{SiO}_{2}$. To our knowledge, the stimulation of methanogenesis by a bivalve was never reported before. As it was hypothesized, S. woodiana is a biogeochemical hot spot affecting benthic processes, but its role is probably neglected in routine measurements due to its low density, which makes its inclusion in random core sampling difficult.
S. woodiana as bioturbator: lateral and vertical movements and ecosystem implications

S. woodiana is reported as suspension feeder, displacing organic particles from the pelagic to the benthic compartment (Pusch et al. 2001). At the study site, which is fed by groundwater, Chl $a$ was very low, suggesting low phytoplankton biomass and food limitation. This may explain the low mollusk density or suggests alternative food sources to the bivalve as sediments, via coupled resuspension and filtration or pedal feeding (Vaughn et al. 2008). Freshwater bivalves redirect and concentrate nutrients and organic matter from the pelagic to the benthic food web through biodeposition of feces and pseudofeces, but if they feed on sediments, choosing high-quality food particles, they rework sediments and favor the regeneration of mineral nutrients to the water column. The upper shell portion of $S$. woodiana hosted a diversified community of algae while that within sediments provided habitat for microbial communities, including purple bacteria. As large amounts of nutrients are regenerated through the exhalant siphon, the occurrence of algae at the upper extreme of the mollusk is not surprising and may result in coupled uptake of regenerated $\mathrm{N}, \mathrm{P}$ and $\mathrm{Si}$.

The bivalve burrowing activity causes sediment bioturbation, which increases the $\mathrm{O}_{2}$ and $\mathrm{NO}_{3}{ }^{-}$ consumption by the sediment and influences the release of sediment-borne nutrients to the water column. Different studies have demonstrated large, apparently erratic lateral movements of unionid mussels, up to $226 \mathrm{~cm}$ per week (Schwalb and Pusch 2007). Horizontal migrations might be related to reproductive needs, to bring animals with opposite sex closer during spawning, which may explain the groups of 2-4 individuals found at the study site (Amyot and Downing 1998). Such explanation fits with what was demonstrated by Burla (1971), with limited lateral movements in the winter and higher in the summer. Alternative hypotheses consider the relevance of water flow and flood, the presence of predators and that of pests like D. polymorpha. Unionid mussels move to deeper waters to avoid exposure to the atmosphere and back to shallower areas when water level rises (McMahon 1991). Furthermore, benthic microalgae may develop in different patches depending on turbidity and nutrient availability and microphytobenthos may represent a food source to unionid 


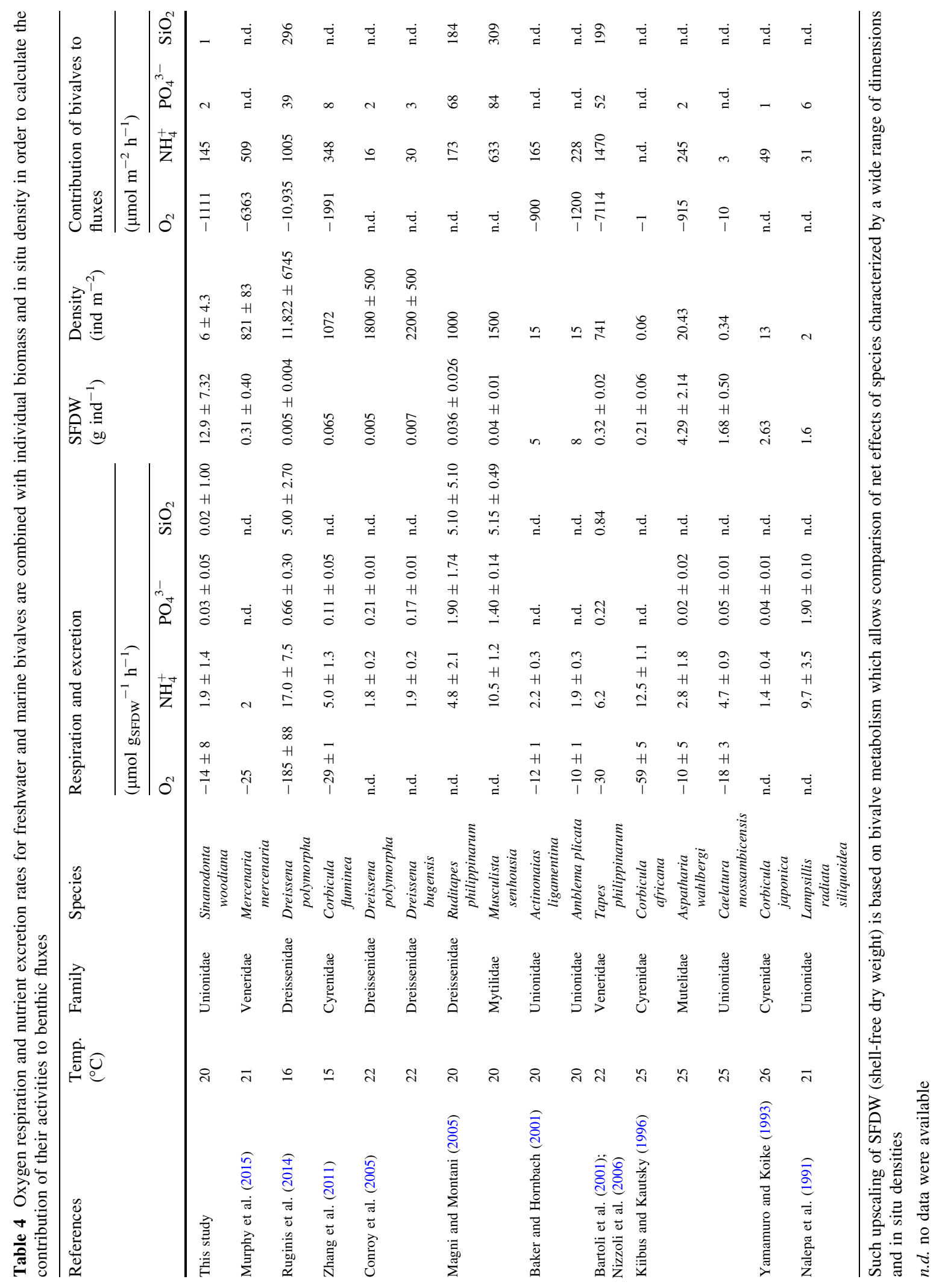


mussels. Horizontal movements may be related to feeding, to access to areas not depleted in food or with higher food quality and the movement itself may be part of the feeding mechanisms (McMahon 1991). Food could be ingested through a focused water current into the anterior portion of unionids (Nichols et al. 2005). If pedal feeding occurs in unionids, this may explain erratic movements and how unionids are able to meet their nutritional needs even at very low seston concentrations (Pusch et al. 2001). Reid et al. (1992) and Yeager et al. (1994) demonstrated that if juvenile bivalves actively pedal-feed their growth is faster than if they only filter water, but this behavior is still not clear for adult forms of unionids. However, Raikow and Hamilton (2001) showed that unionids were consuming $80 \%$ deposited and $20 \%$ suspended material studying a stream labeled with ${ }^{15} \mathrm{~N}$. We speculate that $S$. woodiana adults may feed both pedally and filtering water when there is a low phytoplankton biomass, as observed for Corbicula spp. (Hakenkamp and Palmer 1999).

Water movements created during horizontal or vertical movements may alter the ratio between diffusive and advective solute exchange, and favor the injection of $\mathrm{O}_{2-}$ and $\mathrm{NO}_{3}^{-}$-rich water in anoxic sediments and the mobilization of pore water nutrients or dissolved gas as $\mathrm{CH}_{4}$. All these speculations agree with our results. The gardening effect demonstrated for ants and invoked for burrowing macrofauna may also be carried out by unionids, via sediment fertilization, nutrient mobilization and improvement in light penetration. Resuspension of sediment with benthic microalgae, due to vertical or lateral movement, would provide food to these large organisms and a competitive advantage in clear waters.

Detailed information on sediment-related processes, explaining observed results, are lacking and impede a deep understanding of the functional role of unionid mussels in aquatic ecosystems (Vaughn and Hakenkamp 2001; Strayer 2014). A better understanding of the roles of burrowing bivalves in nutrient cycling and storage in lotic and lentic habitats is needed. In particular, it is central to focus on the origin of food material and on if and how bivalves obtain food from sediments. Moreover, it is important to investigate the differences in feeding between juvenile and adult bivalves and what is being consumed (sediment bacteria, detritus, microphytobenthos).
Further investigations are necessary to know what biotic and abiotic factors regulate bivalve activity. For instance, temperature may stimulate $\mathrm{O}_{2}$ uptake and nutrient fluxes in sediment with and without mollusks (Zhang et al. 2011). The present study is limited as it addresses one season and it focuses on heterotrophic processes, while future studies should investigate a range of temperatures and the processes occurring in the light, including feedbacks between $S$. woodiana and the community of autotrophs.

Direct and indirect contribution of the bivalve to sediment metabolism

Oxygen consumption and $\mathrm{TCO}_{2}$ production in sediments with $S$. woodiana were affected by the mollusk's metabolic activity, significantly enhancing rates measured in bare sediment. Similar results are reported by Bartoli et al. (2001), Nizzoli et al. (2006) and Ruginis et al. (2014) for cultivated $T$. philippinarum and M. galloprovincialis and for the reef-forming $D$. polymorpha, respectively. The slopes of the regressions of $S+A$ or $A$ fluxes versus the dry flesh biomass were not statistically different (Table 3 ), suggesting a prevalent direct role of the mollusk's metabolism and, if present, a minor role of biodeposits in enhancing $\mathrm{O}_{2}$ and $\mathrm{TCO}_{2}$ fluxes. Similar respiration rates in $S+A$ and $A$ suggest higher metabolic activity of $S$. woodiana when incubated outside the sediment.

The effect of $S$. woodiana on anaerobic respiration and on methanogenesis in particular, is a novel and interesting outcome, deserving future studies as it is scarcely explored in the literature (Ruginis et al. 2014). Enhanced production of $\mathrm{CH}_{4}$ and $\mathrm{N}_{2}$ suggests an indirect effect of $S$. woodiana on anaerobic metabolism, which may be due to different factors. Biodeposition may enhance anaerobic activities as already shown in different works, even if potential denitrification and methanogenesis were not stimulated by the addition of feces and pseudofeces to sediment slurries. Large $\mathrm{CH}_{4}$ efflux in the presence of S. woodiana (up to $2.6 \mathrm{mmol} \mathrm{C} \mathrm{m}^{-2} \mathrm{~h}^{-1}$ ) may be a consequence of displacement of labile particles in subsurface anoxic sediments where methane production is the dominant path. Another explanation could be related to the feeding behavior of the mollusk. Ingested bacteria may produce $\mathrm{CH}_{4}$ in the mollusk gut, as demonstrated by Traganza et al. (1979) in anoxic 
micro niches within herbivorous zooplankton digestive track. However, when $S$. woodiana individuals were incubated alone, there was a little production of $\mathrm{CH}_{4}$. This may be a consequence of the interruption of sediment-based feeding and cleaning of the gut. To our knowledge, there are no papers describing the effects of freshwater mollusks on methane production. Different works describe symbiosis between methanotrophic bacteria and deep-sea mussels, with the metabolism of mussels supported by the bacteria (Childress et al. 1986). Symbioses between bivalves and methanotrophs provide the bacteria with access to $\mathrm{CH}_{4}$ and $\mathrm{O}_{2}$ and the bivalve host with a source of organic carbon; rates of $\mathrm{CH}_{4}$ consumption are comparable to those of $\mathrm{O}_{2}$ respiration. Analogously, $\mathrm{CH}_{4}$ oxidizing bacteria were demonstrated to actively grow along the macrofauna burrow walls, resulting in decreased $\mathrm{CH}_{4}$ effluxes in bioturbated versus not bioturbated sediments. In our case, $\mathrm{CH}_{4}$ fluxes are enhanced in the presence of unionids, suggesting also advective pore water movements stimulated by the activity of the large bivalve in such organic and methane-rich sediments.

The presence of the mollusk stimulated also denitrification, as reported for bivalves in fresh and brackish waters (Pelegrí and Blackburn 1995; Nizzoli et al. 2006; Ruginis et al. 2014). In this study, the high rate of total denitrification is a consequence of two factors: one is the high concentration of $\mathrm{NO}_{3}^{-}$in the water that stimulates $D_{\mathrm{W}}$ and the second is the bioturbation by $S$. woodiana that stimulates both components, $D_{\mathrm{W}}$ and $D_{\mathrm{N}}$. The nitrate production measured during the incubation of bivalves alone suggests the presence of nitrifying bacteria associated with the mollusk (Welsh and Castaldelli 2004). The movement of the bivalve increases $\mathrm{NO}_{3}^{-}$and $\mathrm{O}_{2}$ penetration in the sediment and the combination of $\mathrm{O}_{2}$ and the high amount of excreted $\mathrm{NH}_{4}^{+}$could enhance the process of nitrification and the coupled process of denitrification. $D_{\mathrm{N}}$ increased by $63 \%$ in the presence of $S$. woodiana while $D_{\mathrm{W}}$ increased by $40 \%$. Moreover, net $\mathrm{N}_{2}$ efflux confirms the importance of denitrification in the presence of $S$. woodiana and highlights the indirect effect of the mollusk on this process. These net fluxes were lower than the rates measured with the IPT likely due to the occurrence of some $\mathrm{N}$-fixation or because the IPT measures also the labeled $\mathrm{N}_{2}$ accumulated within sediments. Previous studies targeting the effects of mollusks on denitrification report for brackish waters a stimulation of the process. However, rates were one or two orders of magnitude lower than those reported in the present study. Pelegrí and Blackburn (1995) measured denitrification rates between 11 and $13 \mu \mathrm{mol} \mathrm{N} \mathrm{m}{ }^{-2} \mathrm{~h}^{-1}$ in sediments with Cerastoderma sp. and $M$. arenaria, while Nizzoli et al. (2006) measured rates between 70 and $180 \mu \mathrm{mol} \mathrm{N} \mathrm{m}{ }^{-2} \mathrm{~h}^{-1}$ in sediments with T. philippinarum. In a freshwater lake, Ruginis et al. (2014) found that $D$. polymorpha stimulated $\mathrm{N}$ loss by a factor of 1.5 , but reported denitrification rates were two orders of magnitude lower than those from this study. Denitrification efficiency calculated from the ratio between denitrification rates and total inorganic $\mathrm{N}$ effluxes (DIN $+\mathrm{N}_{2}$ ) across the sediment-water interface was $100 \%$ in $\mathrm{S}$ and decreased to $66 \%$ in $S+A$, due to enhanced $\mathrm{NH}_{4}^{+}$recycling by $S$. woodiana. This is in agreement with the general conclusions of Stief (2013) on the net effects of bioturbation on benthic $\mathrm{N}$ cycling, with the stimulation of ammonification and recycling prevailing over $\mathrm{N}$ loss. However, in the canal under study, the presence of $S$. woodiana locally alters benthic $\mathrm{N}$ dynamics while, on average, weighed fluxes of $\mathrm{N}_{2}, \mathrm{NO}_{x}$ and $\mathrm{NH}_{4}^{+}$suggest that denitrification efficiency remains unaltered at $100 \%$. The local net regeneration of $\mathrm{NH}_{4}^{+}$by $S$. woodiana in fact is compensated for the large consumption of $\mathrm{NO}_{3}^{-}$and by $\mathrm{N}_{2}$ production, resulting in negative weighed DIN fluxes.

Nutrient fluxes in the presence of $S$. woodiana

Our results conform to previous studies reporting enhancement of nutrient regeneration in the presence of bivalves (Nalepa et al. 1991; Baker and Hornbach 2001; Ruginis et al. 2014). Sediments with $S$. woodiana net released the mineral forms of the three macronutrients $\mathrm{NH}_{4}^{+}, \mathrm{SRP}$ and $\mathrm{SiO}_{2}$, and incubations of single $S$. woodiana individuals suggest that the bivalve excretion was mainly responsible for such release, as reported in Bartoli et al. (2001) and Ruginis et al. (2014).

The nutrient excretion rates in relation to the density and biomass of mollusks were investigated in several aquatic ecosystems (Table 4). To our knowledge, only a few studies dealt with large mollusks present in low densities such as unionids. Moreover, 
few investigations analyzed the mollusk-related alteration of $\mathrm{N}, \mathrm{Si}$ and $\mathrm{P}$ ecological stoichiometry, which may affect primary producer communities. Small bivalves with high densities have a comparable effect on nutrient excretion as low-density but large individuals as $S$. woodiana (Table 4).

The effect of filter feeders on benthic nutrient cycling was studied more in detail compared to the effect of bivalves exploiting food sources from the sediment, a medium that may contain low-quality organic matter as compared to the water column. At the study site, the sediment had an elevated organic matter content ( $24 \%)$, largely composed of macrophyte fragments from the riparian area ( $P$. australis, Carex spp. and A. donax). We may speculate that this organic matter is recalcitrant, with elevated C-to-N ratios, as nutrient fluxes in bare sediments were all negative, suggesting the need for external nutrient source for mineralization activities. It appears therefore interesting that the ratio between $\mathrm{TCO}_{2}$ and $\mathrm{NH}_{4}^{+}$ fluxes in sediments with $S$. woodiana (nearly 10 ) are similar to those measured in sediments with bivalves feeding on phytoplankton. In other words, this suggests that $S$. woodiana is able to select highquality, labile organic matter within the sediment matrix, such as microphytobenthos or bacteria. Filter feeders, in particular in riverine environments, may concentrate organic matter by removal of phytoplankton from running waters and biodeposition, while organisms feeding on sediments rework the bottom pools of organic matter and improve benthic-pelagic coupling in nutrient-limited environment. We calculated at the study site a molar DIN-to-SRP ratio of 1100 in the water column, suggesting a strong $P$ limitation, which is exacerbated by negative SRP fluxes measured in bare sediment. The activity of $S$. woodiana resulted in reversed SRP fluxes, but the ratio between excreted $\mathrm{NH}_{4}^{+}$and SRP remained elevated (51), and did not alleviate $\mathrm{P}$ limitation. Mobilization of SRP by $S$. woodiana may be related to the pristine environments in which such organism has evolved (i.e., nutrient limited, with low phytoplankton biomass). Such considerations align with what suggested by Strayer (2014), asking for more studies targeting the effects of freshwater mollusks on sedimentary dynamics, the fate of biodeposits and the mollusks nutrient sources. An interesting review (Hölker et al. 2015) analyzes how small chironomid larvae, via their burrowing, bioturbation and filtration activity, may potentially regulate the regime shift between clear and turbid state of shallow lakes but that such a relevant issue is always neglected in limnological studies. Hölker and coauthors list relevant aspects that are missing for a detailed comprehension of the effect of tiny ecosystem engineers in the whole biogeochemical cycles and regulation of planktonic organisms. Similarly, the activity of large, low-density bivalves such as $S$. woodiana should be included in gas and nutrient budgets and, more in general, should be analyzed with respect to the autotrophic and heterotrophic communities, in the context of the whole system functioning.

Acknowledgments Paula Carpintero Moraes was supported by CNPq-Brasil.

\section{References}

Aller RC (1982) The effects of macrobenthos on chemical properties of marine sediment and overlying water. In: McCall PL, Tevest MJT (eds) Animal-sediment relations: the biogenic alteration of sediment, 2nd edn. Plenum Press, New York, pp 53-102

Amyot JP, Downing J (1998) Locomotion in Elliptio complanata (Mollusca: Unionidae): a reproductive function? Freshwater Biol 39:351-358

Anderson LG, Hall POJ, Iverfeldt A et al (1986) Benthic respiration measured by total carbonate production. Limnol Oceanogr 31:319-329

Baker SM, Hornbach DJ (2001) Seasonal metabolism and biochemical composition of two unionid mussels, Actinonaias ligamentina and Amblema plicata. J Mollus Stud 67:407-416

Balfour DL, Smock LA (1995) Distribution, age structure, and movements of the freshwater mussel Elliptio complanata (Mollusca: Unionidae) in a headwater stream. J Freshwater Ecol 10:255-268

Bartoli M, Nizzoli D, Welsh DT, Viaroli P (2000) Short-term influence of recolonisation by the polycheate worm Nereis succinea on oxygen and nitrogen fluxes and denitrification: a microcosm simulation. Hydrobiologia 431:165-174

Bartoli M, Nizzoli D, Viaroli P, Turolla E, Castaldelli G, Fano EA, Rossi R (2001) Impact of Tapes philippinarum farming on nutrient dynamics and benthic respiration in the Sacca di Goro. Hydrobiologia 455:203-212

Bartoli M, Naldi M, Nizzoli D, Roubaix V, Viaroli P (2003) Influence of clam farming on macroalgal growth: a microcosm experiment. Chem Ecol 19:147-160

Bartoli M, Longhi D, Nizzoli D, Como S, Magni P, Viaroli P (2009) Short term effects of hypoxia and bioturbation on solute fluxes, denitrification and buffering capacity in a shallow dystrophic pond. J Exp Mar Biol Ecol 381:105-113 
Bower CE, Holm-Hansen T (1980) A salicylate-hypochlorite method for determining ammonia in seawater. Can J Fish Aquat Sci 37:794-798

Burla H (1971) Gerichtete Ortsveränderung bei Muscheln der Gattung Anodonta im Zürichsee. Vierteljahrsschrift Der Naturforschenden Gesellschaft in Zürich 116:181-194

Caraco NF, Cole JJ, Findlay SEG, Lampman GG, Pace ML, Strayer DL (2000) Dissolved oxygen declines in the Hudson River associated with the invasion of the zebra mussel (Dreissena polymorpha). Environ Sci Technol 34:1204-1210

Childress JJ, Fisher CR, Brooks JM, Kennicutt MC II, Bidigare $\mathrm{R}$, Anderson AE (1986) A methanotrophic marine molluscan (Bivalvia, Mytilidae) symbiosis: mussels fueled by gas. Science 233:1306-1308

Conroy JD, Edwards WJ, Pontius RA, Kane DD, Zhang H, Shea JF, Culver A (2005) Soluble nitrogen and phosphorus excretion of exotic freshwater mussels (Dreissena spp.): potential impacts for nutrient remineralization in western Lake Erie. Freshwater Biol 50:1146-1162

Dalsgaard T, Nielsen LP, Brotas V et al (2000) Protocol handbook for NICE-nitrogen cycling in estuaries: a project under the EU research programme. In: Marine Science and Technology (MAST III), National Environmental Research Institute, Silkeborg

Gallepp GW (1979) Chironomid influence on phosphorus release in sediment-water microcosms. Ecology 60:547-556

Glud RN, Blackburn N (2002) The effects of chamber size on benthic oxygen uptake measurements: a simulation study. Ophelia 56:23-31

Golterman HL, Clymo RS, Ohnstand MAM (1978) Methods for physical and chemical analysis of fresh waters. In: I.B.P. Handbook Nr. 8. Blackwell, Oxford

Hakenkamp CC, Palmer MA (1999) Introduced bivalves in freshwater ecosystems: the impact of Corbicula on organic matter dynamics in a sandy stream. Oecologia 119:445-451

Hansen K, King GM, Kristensen E (1996) Impact of the softshell clam Mya arenaria on sulfate reduction in an intertidal sediment. Aquat Microb Ecol 10:181-194

Higgins SN, Zanden MJV (2010) What a difference a species makes: a meta-analysis of dreissenid mussel impacts on freshwater ecosystems. Ecol Monogr 80:179-196

Hölker F, Vanni MJ, Kuiper JJ et al (2015) Tube-dwelling invertebrates: tiny ecosystem engineers have large effects in lake ecosystems. Ecol Monogr 85:333-351

Kiibus M, Kautsky N (1996) Respiration, nutrient excretion and filtration rate of tropical freshwater mussels and their contribution to production and energy flow in Lake Kariba, Zimbabwe. Hydrobiologia 331:25-32

Kristensen E, Penha-Lopes G, Delefosse M, Valdemarsen T, Quintana CO, Banta GT (2012) What is bioturbation? The need for a precise definition for fauna in aquatic sciences. Mar Ecol Prog Ser 446:285-302

Lorenzen CJ (1967) Determination of chlorophyll and phaeopigments: spectrophotometric equations. Limnol Oceanogr 12:343-346

Magni P, Montani S (2005) Laboratory experiments on bivalve excretion rates of nutrients. Water Encycl 4:6-11
Manganelli G, Bodon M, Favilli L, Castagnolo L, Giusti F (1998) Checklist of the species of the Italian fauna, terrestrial and freshwater mollusks. Bollettino Malacologico Italiano 33:151-156

McMahon RF (1991) Mollusca: Bivalvia. In: Thorp JH, Covich AP (eds) Ecology and classification of North American freshwater invertebrates. Academic Press, San Diego, pp 315-399

Murphy AE, Anderson IC, Luckenbach MW (2015) Enhanced nutrient regeneration at commercial hard clam (Mercenaria mercenaria) beds and the role of macroalgae. Mar Ecol Prog Ser 530:135-151

Na T, Gribsholt B, Galaktionov OS, Lee T, Meysman FJR (2008) Influence of advective bio-irrigation on carbon and nitrogen cycling in sandy sediments. $\mathrm{J}$ Mar Res 66:691-722

Nalepa TF, Gardner WS, Malczyk JM (1991) Phosphorus cycling by mussels (Unionidae: Bivalvia) in Lake St. Clair. Hydrobiologia 219:239-250

Nichols SJ, Silverman H, Dietz TH, Lynn JW, Garling DL (2005) Pathways of food uptake in native (Unionidae) and introduced (Corbiculidae and Dreissenidae) freshwater bivalves. J Great Lakes Res 31:87-96

Nielsen LP (1992) Denitrification in sediment determined from nitrogen isotope paring. FEMS Microbiol Ecol 86:357-362

Nizzoli D, Welsh DT, Fano EA, Viaroli P (2006) Impact of clam and mussel farming on benthic metabolism and nitrogen cycling, with emphasis on nitrate reduction pathways. Mar Ecol Prog Ser 315:151-165

Nizzoli D, Bartoli M, Cooper M, Welsh DT, Underwood GJC, Viaroli P (2007) Implications for oxygen, nutrient fluxes and denitrification rates during the early stage of sediment colonisation by the polychaete Nereis spp. in four estuaries. Estuar Coast Shelf Sci 75:125-134

Nizzoli D, Welsh DT, Longhi D, Viaroli P (2014) Influence of Potamogeton pectinatus and microphytobenthos on benthic metabolism, nutrient fluxes and denitrification in a freshwater littoral sediment in an agricultural landscape: $\mathrm{N}$ assimilation versus $\mathrm{N}$ removal. Hydrobiologia 737:183-200

Norkko J, Reed DC, Timmermann K et al (2012) Welcome can of worms? Hypoxia mitigation by an invasive species. Glob Change Biol 18:422-434

Palmer MA, Covich AP, Finlay BJ et al (1997) Biodiversity and ecosystem processes in freshwater sediments. Ambio 26:571-577

Pelegrí SP, Blackburn TH (1995) Effects of Tubifex tubifex (Oligochaeta: Tubificidae) on N-mineralization in freshwater sediments, measured with ${ }^{15}$ isotopes. Aquat Microb Ecol 9:289-294

Pelegrí SP, Nielsen LP, Blackburn TH (1994) Denitrification in estuarine sediment stimulated by the irrigation activity of the amphipod Corophium volutator. Mar Ecol Prog Ser 105:285-290

Prins TC, Smaal AC, Dame RF (1998) A review of the feedbacks between bivalve grazing and ecosystem processes. Aquat Ecol 31:349-359

Pusch M, Siefert J, Walz N (2001) Filtration and respiration rates of two unionid species and their impact on the water quality of a lowland river. In: Bauer G, Wächtler K (eds) 
Ecology and evolution of the freshwater mussels Unionidae. Springer, Berlin, pp 317-326

Raikow DF, Hamilton SK (2001) Bivalve diets in a midwestern U.S. stream: a stable isotope enrichment study. Limnol Oceanogr 46:514-522

Reid RGB, McMahon RF, Foighil DO, Finnigan R (1992) Anterior inhalant currents and pedal feeding in bivalves. The Veliger 35:93-104

Rota E, Bartoli M, Laini A (2014) First time in Italy. Is the elusive aquatic megadrile Sparganophilus Benham, 1892 (Annelida, Clitellata) accelerating its dispersal in Europe? J Limnol 73:482-489

Ruginis T, Bartoli M, Petkuviene J, Zilius M, Lubiene I, Laini A, Razinkovas-Baziukas A (2014) Benthic respiration and stoichiometry of regenerated nutrients in lake sediments with Dreissena polymorpha. Aquat Sci 76:405-417

Schwalb AN, Pusch MT (2007) Horizontal and vertical movements of unionid mussels in a lowland river. $\mathrm{J} \mathrm{N} \mathrm{Am}$ Benthol Soc 26:261-272

Stadmark J, Conley DJ (2011) Mussel farming as a nutrient reduction measure in the Baltic Sea: consideration of nutrient biogeochemical cycles. Mar Pollut Bull 62:1385-1388

Stief P (2013) Stimulation of microbial nitrogen cycling in aquatic ecosystems by benthic macrofauna: mechanisms and environmental implications. Biogeosciences 10:7829-7846

Strayer DL (2014) Understanding how nutrient cycles and freshwater mussels (Unionoida) affect one another. Hydrobiologia 735:277-292

Strayer DL, Hunter DC, Smith LC, Borg C (1994) Distribution, abundance, and role of freshwater clams (Bivalvia: Unionidae) in the freshwater tidal Hudson River. Freshwater Biol 31:239-248

Svensson JM (1997) Influence of Chironomus plumosus larvae on ammonium flux and denitrification (measured by the acetylene blockage- and the isotope pairing-technique) in eutrophic lake sediment. Hydrobiologia 346:157-168
Thamdrup B, Dalsgaard T (2002) Production of $\mathrm{N}_{2}$ through anaerobic ammonium oxidation coupled to nitrate reduction in marine sediments. Appl Environ Microbiol 68:1312-1318

Traganza ED, Swinnerton JW, Cheek CH (1979) Methane supersaturation and ATP-zooplankton blooms in nearsurface waters of the Western Mediterranean and the subtropical North Atlantic Ocean. Deep Sea Res Part 1 Oceanogr Res Pap 26:1237-1245

Valderrama JC (1977) Methods used by the hydrographica department of the national board of fisheries. Goteborg, Sweden

Vaughn CC, Hakenkamp C (2001) The functional role of burrowing bivalves in freshwater ecosystems. Freshwater Biol 46:1431-1446

Vaughn CC, Gido KB, Spooner DE (2004) Ecosystem processes performed by unionid mussels in stream mesocosms: species roles and effects of abundance. Hydrobiologia 527:35-47

Vaughn CC, Nichols SJ, Spooner DE (2008) Community and foodweb ecology of freshwater mussels. J N Am Benthol Soc 27:409-423

Welsh DT, Castaldelli G (2004) Bacterial nitrification activity directly associated with isolated benthic marine animals. Mar Biol 144:1029-1037

Yamamuro M, Koike I (1993) Nitrogen metabolism of the filterfeeding bivalve Corbicula japonica and its significance in primary production of a brackish lake in Japan. Limnol Oceanogr 38:997-1007

Yeager MM, Cherry DS, Neves RJ (1994) Feeding and burrowing behaviors of juvenile rainbow mussels Villosa iris (Bivalvia:Unionidae). J N Am Benthol Soc 13:217-222

Zhang L, Shen Q, Hu H, Shao S, Fan C (2011) Impacts of Corbicula fluminea on oxygen uptake and nutrient fluxes across the sediment-water interface. Water Air Soil Poll 220:399-411 